\title{
Ecotourism Governance Based on Community Participation
}

\author{
Rita Rahmawati \\ Djuanda University (email: rita.rahmawati@unida.ac.id)
}

Afmi Apriliani

\begin{abstract}
Sukagalih Village is one of the Conservation Village Models in the Mount Halimun Salak National Park area, which is a form of community participation in culture-based tourism management. Its location in the Mount Halimun Salak National Park area makes this location a potential ecotourism village. The purpose of this study was to determine the governance of Ecotourism Development based on community participation in Sukagalih Village. The research method used is descriptive with a qualitative approach. The data collection technique used interviews and participant observation. Based on the research results, the management of Sukagalih Ecotourism uses the CBE (community-based ecotourism) approach. The community-based ecotourism pattern recognizes the rights of local communities in managing tourism activities in areas they traditionally own or as managers. Through local institutions, the community is very actively involved in ecotourism management, namely through the provision of homestays for every tourist, community involvement through the management of outbound and camping ground. However, there are still various obstacles, so it still requires local government intervention to develop this ecotourism.
\end{abstract}

\section{Keywords:}

governance; ecotourism; institutional; community-based ecotourism

\section{Introduction}

Indonesia has the potential for natural beauty and cultural wealth that are of high value in the ecotourism industry market. The natural potential can be in the form of biological natural resources and their ecosystems, diversity of flora, fauna, and natural phenomena with unspoiled scenic beauty. For culture, Indonesia has a system of religion, arts, regional languages, cultural rites, knowledge, and social organization. Based on a report from the World Travel Tourism Council (WTTC) in 2000, ecotourism grew by an average of 10 percent per year. This figure is higher than the average growth per year for tourism in general, which is 4.6 percent per year. As a form of tourism, ecotourism has its own specialties, namely prioritizing environmental conservation, environmental education, the welfare of local residents, and respecting local culture. 
In Law Number 10 of 2009 concerning Tourism, tourism development is needed to encourage equal opportunity to do business and get benefits and be able to face the challenges of changing local, national and global life. One of the goals of tourism development is to increase economic growth; improve community welfare; eradicating poverty; overcoming unemployment; conserving nature, environment and resources; as well as preserving and advancing culture. Ecotourism development will provide benefits in boosting community welfare through the development of tourism potential by raising local wisdom. With implication as follows:

- Tourism destination development must be based on sustainability

- Social and economic benefits may derived from tourism area without destructing the environment and local cultures.

- Tourist behavior and code of ethics of tourism form an integral part in realization of sustainable development

Sukagalih Village is one of the conservation village models (MKK) located in the Mount Halimun Salak National Park (TNGHS). The Conservation Village Model is a translation of the Conservation Village Model (a conservation area management approach carried out by the Directorate General of PHKA) which is implemented by the Mount Halimun Salak National Park. MKK appears as a management model to respond to changes in the paradigm of conservation area management by collaborating with the surrounding community and in the area to manage and maintain the GHSNP area which is supported by three pillars of activities, namely participatory observation, restoration / rehabilitation, and income generating / increasing the community's economy.

The Conservation Village Model is a village model in which it can carry out protection activities independently, maintain a good ecosystem and can economically provide welfare for the community. The vision that was carried was that the community lived with the National Park. Based on the results of interviews with the Sukagalih MKK Manager, he said that there was a positive impact with the existence of the Conservation Village Model. One of the efforts to increase income generating is to promote the concept of ecotourism.

Ecotourism is part of sustainable tourism. Sustainable Tourism is an economic sector that is broader than ecotourism which includes sectors that support tourism activities in 
general, including marine tourism (Beach and sun tourism), rural tourism (rural and agro tourism) or, business travel (business travel). According to the Ministry of Culture and Tourism of the Republic of Indonesia, ecotourism is a concept of sustainable tourism development that aims to support efforts to conserve the environment (nature and culture) and increase community participation in management, thereby providing economic benefits to the community and local government (Zalukhu, 2009).

Meanwhile in the Minister of Home Affairs Regulation No. 33 of 2009 concerning Guidelines for the Development of Ecotourism in the Regions provides a definition of ecotourism, namely natural tourism activities in the regions that are responsible by paying attention to elements of education, understanding, and support for natural resource conservation efforts and increasing local community income.

As one of the Conservation Committees in Mountain Halimun Salak National Park area, Sukagalih village has diverse ecotourism potential, namely the charm of natural beauty and unique cultural values that exist in the community, where all Sukagalih residents are given an understanding of the importance of improving their performance. The residents there have been patterned to maintain the beauty of their village. The houses of residents are also arranged in such a way that on weekend many tourists, both domestic and foreign, rent a house to spend the week end in their village. They are not only limited to providing their houses for rent, they also provide breakfast, lunch and dinner services.

\section{Purpose of Study}

The purpose of this study was to determine the Management of Ecotourism Based on Local Culture in the Sukagalih Conservation Village.

\section{Methods}

The research method used is qualitative research with a qualitative descriptive approach. Qualitative analysis was carried out on data on Ecotourism Governance in Sukagalih Village, where data was obtained from observations, literature studies, reports and supporting documents. The location taken is Sukagalih Village, Cipeuteuy Village, which is directly adjacent to TNGHS in Sukabumi district. The reason for choosing the village was because it was one of the villages that was used as the Pilot Project for the Development of 
Conservation Villages. The Mount Halimun Salak National Park area also has unique natural tourism potential, values and culture in the community. $T$ the researchers determined Sukagalih Village as the research location. In this study the researchers obtained data from 15 informants consisting of officers from Mount Halimun Salak National Park, village officials, person in charge of MKK and a number of selected villagers.

\section{Result and Discussion}

As an effort to support the preservation of the National Park, Mount Halimun Salak National Park has a special management for ecotourism activities. Several areas in the utilization zone are used for ecotourism activities. Mount Halimun Salak National Park made the "Halimun Salak Mountain National Park Ecotourism Development Action Plan." The Ecotourism Development Action Plan (RAPE) was prepared as a reference material for collaborative ecotourism development that is being implemented by TNGHS. It is stated in the GHSNP management plan that management related to the implementation of natural tourism includes many things that must be realized. The management plan aims at the sustainable use of natural resources. Mount Halimun Salak National Park divides the area into several categories in its use as a tourist area. The management model is exclusive tourism, eco-tourism, and mass tourism / recreational tourism.

The International Ecotourism Society defines ecotourism as responsible travel to natural areas that conserves the environment and sustains the well-being of local people (cited in Honey, 1999a). Ecotourism has been promoted as a non-consumptive use of nature and as a possible win-win development strategy, especially for underdeveloped areas (a.o. Boo, 1990; Honey, 1999b; Weaver, 2001). Ecotourism should not only conserve the envi-ronment, but also improve the welfare of local people (Edwards et al.1998). It should generate money in an ecologically and socially friendly way than other forms of land exploitation.

Ecotourism in Indonesia defined as "activities of responsible travelling in intact areas or in areas which are named according to the role of nature"

The purpose of such activities are:

- being to enjoy natural beauty

- involving education, understanding, and supports conservation,

- as well as increasing the income of the local communities 
One of the ecotourism locations developed by BTNGHS is the ecotourism of Sukagalih Village, Sukagalih Village, Cipeuteuy Village, Kabandungan District, Sukabumi Regency which is a village located in the Mount Halimun Salak National Park (TNGHS). Administratively, Kampung Sukagalih, Cipeuteuy Village is located in Kabandungan District, Sukabumi Regency, West Java Province. Kampung Sukagalih is not only located around the area but directly adjacent to the GHSNP area. Several villages are located in the vicinity of the area, namely Purwabakti Village to the north, to the south of Cimaherang Village, to the west of Malasari Village and to the east of Kabandungan Village.

Institutionally, the Mount Halimun Salak National Park Agency (BTNGHS) is responsible for ecotourism management, but the technical management is left to the community, management is carried out by a community group called KOPEL (Nature Conservation Group). strives to improve welfare both materially and non-material (spiritual) through educational activities, agriculture, fisheries, animal husbandry and exploring the potential of natural resources and the use of environmental services, non-timber forest products and other supporting activities. The area of the settlement is about 5 hectares with a population of 115 people, 40 heads of families (KK) and 37 houses. Sukagalih community groups are oriented towards welfare, care, awareness and togetherness that are tied to kinship and mutual cooperation.

The ecotourism area of Sukagalih village includes an enclave that connects the Mount Halimun area with Mount Salak. The number of unique sites that have the potential to be developed as tourist sites, including camping ground, resin plantations, bamboo forests, riparian areas / along rivers (Cimelati River, etc.), agro-tourism (rice, chilies, tomatoes, vegetables, coffee, bananas), etc.), medicinal plants area, birdwatching area, observation area for primate mammals (surili and apes). Besides that, it is also supported by inherent local wisdom values such as hospitality, strong mutual cooperation. The supporting facilities for ecotourism in Sukagalih village include a meeting hall, 1 mosque and 2 toilets.

Based on the results of interviews with the managers of Sukagalih Village, it was stated that Sukagalih Village had a unique habit, which was known as arisan Tenaga, where all residents would help other residents' hard work. For example, if a resident has several rice fields to be processed and planted with rice, all residents will work together to plow, plant, and harvest the fields of the residents who need assistance. Likewise, in the construction of 
house buildings, residents do not need to pay coolies or builders to complete their dwellings, all Sukagalih residents will work together to help, as a condition is that the people who are assisted have debts (are obliged to) help the work of those who have helped them when needed.

Community involvement is very full in ecotourism management both from planning, implementing, and managing ecotourism businesses and all the benefits obtained show that the management of Sukagalih Ecotourism uses a CBE (community-based ecotourism) approach. The community-based ecotourism pattern recognizes the rights of local communities in managing tourism activities in the areas they have traditionally or as managers.

Based on the Regulation of the Minister of Home Affairs Number 33 of 2009, the principles of ecotourism development include: (1) compatibility between types and characteristics of ecotourism; (2) conservation, namely protecting, preserving, and making sustainable use of natural resources used for ecotourism; (3) economic, namely providing benefits to the local community and being a driving force for economic development in the region and ensuring that ecotourism business can be sustainable; (4) education, which contains elements of education to change a person's perception in order to have concern, responsibility and commitment to environmental and cultural preservation; (5) provide satisfaction and experience to visitors; (6) community participation, namely community participation in planning, exploiting, and controlling ecotourism activities by respecting the socio-cultural and religious values of the communities around the area; and (7) accommodating local wisdom.

Referring to the book of principles and criteria for community-based ecotourism by the Directorate of Tourism Products, Directorate General of Tourism Destination Development, Ministry of Culture and Tourism in collaboration with WWF-Indonesia January 2009, it is stated that community-based ecotourism is an ecotourism business that emphasizes the active role of the community. This is based on the fact that the community has knowledge of nature and culture which are potential and selling points as a tourist attraction, so that community involvement is absolute. The community-based ecotourism pattern recognizes the rights of local communities in managing tourism activities in the areas they have traditionally or as managers. 
Furthermore, it was conveyed that community-based ecotourism can create job opportunities for local communities, and reduce poverty, where the ecotourism income is from tourism services for tourists: guide fees; transportation costs; homestay; selling crafts, etc. Ecotourism has a positive impact on the preservation of the environment and local indigenous culture which in the end is expected to be able to foster an identity and a sense of pride among local residents that has grown due to the increase in ecotourism activities.

Some of the key aspects of community-based ecotourism are:

- The community forms a committee or institution to manage activities ecotourism in the area, with support from government and organizations community (the value of community participation and education)

- The principle of local ownership (management and ownership by local communities) is applied wherever possible to ecotourism facilities and infrastructure, ecotourism areas, etc. (value of community participation)

- Homestay is the main choice for accommodation in tourist locations (value economics and education).

- The guide is a local person (value of community participation)

- Pioneering, managing and maintaining tourism objects is the responsibility local communities, including determining fees for tourists (economic and tourism value).

\section{Impact of Ecotourism}

The impact is a change that occurs as a result of an activity (Soemarwoto, 1989). Ecotourism is an important sector in development. Good ecotourism management will yield several benefits in various aspects. However, if not managed properly, then ecotourism can potentially cause problems or negative impacts. Based on a macroeconomic perspective, ecotourism has several positive impacts (Yoeti, 2008), namely:

1. Creating business opportunities;

2. Creating job opportunities;

3. Increasing income as well as accelerating the distribution of people's income, as a result of the multiplier effect that occurs from relatively large tourist expenditures;

4. Increase government tax revenue and local user fees; 
5. Increase the national income or Gross Domestic Gross (GDB);

6. Encouraging increased investment from the tourism industry sector and other economic sectors;

7. Strengthening the balance of payments. If the balance of payments experiences a surplus, it will automatically strengthen Indonesia's balance of payments, and vice versa.

Development of ecotourism not only has a positive impact but can also have several negative impacts, among others (Yoeti, 2008):

1. Biological resources are damaged, which causes Indonesia to lose its attractiveness in the long term;

2. Littering which, apart from causing an unpleasant odor, can also kill the surrounding plants;

3. There is frequent commercialization of arts and culture; and

4. There was a demonstration effect, the personality of the young people was damaged. The way children dressed was worldwide wearing t-shirts and oversized trousers.

\section{The Effect of Ecotourism Development on Socio-Culture}

Ecotourism as tourism industry is part of a cultural industry that involves the entire community. Although only part of the community is involved, social influence is wider, such as the occurrence of social inequality/disparity in society. The influence of tourism on society includes changes in social processes in which there is cooperation and competition between tourism actors. Social processes are reciprocal relationships between individuals, individuals, and groups, and between groups, based on their respective potentials or strengths (Abdulsyani, 1994).

The social process is a dynamic aspect of community life where there is a process of human relations in the form of social interactions that occur in human life continuously. The formation of social interactions when there are social contact and social communication. Social processes can take various forms, namely, cooperation, competition, contention/conflict, and accommodation (Tafalas, 2010). 


\section{The Effect of Ecotourism Development on the Economy}

According to Sedarmayanti (2005), ecotourism activities that attract many tourists have contributed to foreign exchange for the country and have also opened job opportunities for the surrounding community. The community not only gets jobs and increases in income but can also create new jobs that support tourism activities. The standard of living is quoted from BPS data for 2005 in Rahman (2009) as the poverty variable, namely the area of the floor of a residence, the type of floor of a residential building. defecation facilities, household lighting sources, drinking water sources, cooking fuel, consumption of meat/chicken/milk / per week, buying new clothes for each household member every year, frequency of meals per day, ability to pay for medical treatment at a health center or doctor, occupation of the head of the household, the highest education level of the head of the household and ownership of movable and immovable assets/assets. Standard of living is the level of ability to meet the needs of life.

Based on the results of interviews with one of the communities and ecotourism managers, it is stated that the community is very actively involved in ecotourism management, namely through the provision of simple homestay facilities for each tourist, there are 15 homestays available which also provide special food for tourists who want to visit Sukagalih village, besides that the community involvement through Outbound and Camping Ground management, planting of endemic species and attractions of village community activities in managing agricultural land and protecting forests.

Culture-based ecotourism management in Sukagalih Village can be said to be quite successful in providing a positive impact both for the villagers, the social life of the villagers, improving the economy of the Sukagalih village community and preserving the environment and local culture. The community since playing an active role in the management of Sukagalih village in an ecotourism manner has increasingly understood the importance of preserving the environment. The management of tourism areas by means of ecotourism is proven to be able to provide new jobs for villagers through the provision of homestays and local culinary delights.

Following Stern et al. (2003), we expect that scale has an influence upon the impacts of tourism. We presume that a larger scale will give greater benefits, but also more draw-backs. 
In the end, we expect the drawbacks to dominate the benefits in case of large-scale tourism. A second presumption is that we expect a larger involvement of the local population to result in greater benefits and lesser drawbacks. This expectation stems from the view point that sustainable tourism requires the involvement of local residents in its operations (Barkin, 2003; Lindberg et al., 1996; Wunder, 2000). Finally, we believe that a greater institutional capacity of a region will result in more sustainable tourism, because this allows for a better planning of the ecotourism facilities.

However, on the other hand, the management of ecotourism in Sukagalih Village still has obstacles, including: the lack of knowledge of residents about ecotourism management; still low accessibility and infrastructure for environmental management of tourist sites; Tourism facilities and infrastructure such as based on the results of interviews with Cipeutey village officials, it was found that in the management of Sukagalih ecotourism, the constraints faced were the lack of budget and information resources. The source of the ecotourism operational budget is from the results of accommodation packages such as culinary delights and homestays, however this is so small that the development and maintenance of ecotourism facilities is considered insufficient.

Another obstacle, as mentioned by the tourism manager, is the low accessibility of tourist attractions. To get to the village of Sukagalih village, the roads are uphill and winding, you can use four-wheeled or two-wheeled vehicles. Sukagalih Village is $1 \mathrm{~km}$ from the Cipeteuy village office with a travel time of 10 minutes using a vehicle, $4 \mathrm{~km}$ from the District with a travel time of 25 minutes using a vehicle, $57 \mathrm{~km}$ from the district with a travel time of 120 minutes using a vehicle, 136 from the Province with a travel time of 5-6 hours using a vehicle and $107 \mathrm{~km}$ from Jakarta with a travel time of 3-4 hours using a vehicle. The road structure is damaged especially during rainy conditions. this reduces the convenience of visitors to Sukagalih Village.

In addition, ecotourism managers really need a special place (secretariat) for acceptance or an information center for Ecotourism in Sukagalih Village for every tourist. So far, tourist admission is still carried out at the Meeting Hall or the house of one of the residents. As for the Marketing / Promotion of Sukagalih Ecotourism, according to one of the officers of the Mount Halimun Salak National Park, it is considered still lacking, especially Promotion through Digital Media. For example, there are several websites that review Sukagalih Village 
Tour, but information is rarely updated, even though through digital promotions it can be faster and easier.

\section{Conclusion}

Culture-based ecotourism management in Sukagalih Village can be said to be quite successful in providing a positive impact both for the villagers, the social life of the villagers, improving the economy of the Sukagalih village community and preserving the environment and local culture. The community since playing an active role in the management of Sukagalih village in an ecotourism manner has increasingly understood the importance of preserving the environment. The management of tourism areas by means of ecotourism is proven to be able to provide new jobs for villagers through the provision of homestays and local culinary delights.

However, on the other hand, the management of ecotourism in Sukagalih Village still has obstacles, including: the lack of knowledge of residents about ecotourism management; still low accessibility and infrastructure for environmental management of tourist sites; Tourism facilities and infrastructure such as a special place (secretariat) for the reception of every tourist and a special track for outbound. Thus the recommendations of this study are strengthening local institutions, increasing the budget, improving infrastructure, and increasing accessibility.

\section{Reference}

Abdulsyani. 1994. Sosiologi Skematika, Teori dan Terapan. Jakarta (ID): Bumi Aksara.

Barkin, D. (2003). Alleviating poverty through ecotourism: Promises and reality in the Monarch butterflyreserve of Mexico.Environment, Development and Sustainability, 5, $371-382$.

Boo, E. (1990).Ecotourism: The potentials and pitfalls. WWF: Washington, DC

Edwards, S. N., McLaughlin, W. J., \& Ham, S. H. (1998). Comparative study of ecotourism policy in the Americas: Volume II-Latin America and the Caribbean. Idaho: University of Idaho.

GHSNP MP JICA. 2008. Rencana Aksi Pengembangan Ekowisata Taman Nasional Gunung Halimun Salak 2008-2021. Balai Taman Nasional Gunung Halimun Salak: Jawa Barat. 
Honey, M. (1999a). Ecotourism and sustainable development. Who owns paradise?. Washington, DC: Island Press

Honey, M. (1999b). Treading lightly? 'Ecotourism's impact on the environment'. Environment, 41(5), 4-16.

Lindberg, K., Enriquez, J., \& Sproule, K. (1996). Ecotourism questioned: Case studies from Belize.Annalsof Tourism Research, 23(3), 543-562.

Peraturan Pemerintah Nomor 18 Tahun 1994 tentang Pengusahaan Pariwisata Alam di Zona Pemanfaatan Taman Nasional, Taman Hutan Raya, dan Taman Wisata Alam (Lembaran Negara Republik Indonesia Tahun 1994 Nomor 25, Tambahan Lembaran Negara Republik Indonesia Nomor 3550);

Permendagri No. 33 Tahun 2009 Tentang Pedoman Pengembangan Ekowisata di Daerah.

Prinsip dan kriteria ekowisata berbasis masyarakat Kerjasama Direktorat Produk Pariwisata Direktorat Jenderal Pengembangan Destinasi Pariwisata Departemen Kebudayaan dan Pariwisata dengan WWF-Indonesia Januari 2009

Rahman, A. 2009a. Evaluasi Tanggung Jawab Sosial PT Holcim Indonesia Tbk (Studi Kasus Baitul Maal wa Tamwil Swadaya Pribumi, Kecamatan Klapanunggal, Kabupaten Bogor, Provinsi Jawa Barat) [skripsi]. Bogor [ID]: Institut Pertanian Bogor.

Sedarmayanti. 2005. Membangun Kebudayaan dan Pariwisata (Bunga Rampai Tulisan Pariwisata). Bandung (ID): Penerbit Mandar Maju.

Stern, C. J., Lassoie, J. P., Lee, D. R., \& Deshler, J. D. (2003). How 'eco' is ecotourism? A comparative casestudy of ecotourism in Costa Rica.Journal of sustainable tourism, 11(4), 322-347

Suparmo, M et al. 2008. Rencana Aksi Pengembangan Ekowisata Taman Nasional Gunung Halimun Salak 2008-2011. Sukabumi [ID]: Balai Taman Nasional Gunung Halimun Salak. Tafalas, M. 2010. Dampak Pengembangan Ekowisata terhadap Kehidupan Sosial dan Ekonomi Masyarakat lokal studi kasus ekowisata bahari Pulau Mansuar Kabupaten Raja Ampat [tesis]. Bogor (ID): Institut Pertanian Bogor. Tuwo A. 2011. Pengelolaan Ekowisata Pesisir dan Laut. Surabaya (ID): Brilian Internasional.

Undang-undang No.10 Tahun 2009 tentang Kepariwisataan.

Weaver, D. B. (2001). Ecotourism as mass tourism: Contradiction or reality? Cornell Hotel and Restaurant Administration Quarterly, 42(2), 104-112. 
Wunder, S. (2000). Ecotourism and economic incentives - an empirical approach.Ecological Economics,32(3), 465-479.

Yoeti, OA. 2008. Ekonomi Pariwisata: Introduksi, Informasi, dan Implementasi. Jakarta (ID): Kompas.

Zalukhu, Sukawati. 2009. Buku Panduan Dasar Pelaksanaan Ekowisata Kabupaten Nias Selatan. 